\title{
LADINA KEELE ÕPPIMISEST TEOLOOGIAS PRAKTILISEST KÜLJEST
}

Keele ja Kirjanduse veebruarikuu numbris avaldas Anne Lill põhjaliku retsensiooni õpikule „Lingua Latina in theologia", ${ }^{1}$ kus ta analüüsis raamatus leiduvat ja puuduvat. Käsitlus on igati tänuväärne, seda enam, et ladina keele õppimisega seonduvast kirjutatakse harva. Ent arvustuses tõstatatud probleemidele retsensent lahendusi pakkunud ei ole. Seega lisan nii omapoolsed selgitused selle raamatu koostamise põhimõtete kohta kui ka võimalike puudujääkide korvamise võimaluse.

Erinevate valdkondade ladina keele õppel on omad iseärasused ja lähenemiseks on võimalusi rohkem kui üks. Ka raamatul „Lingua Latina in theologia" on spetsiifilise taustaga sihtrühm, mida tuli õpiku koostamisel arvestada. Eelkõige on õppevahend mõeldud teoloogiatudengitele, kes enne ladina keele õppimise alustamist on tavaliselt juba õppinud heebrea ja kreeka keelt ning vahel ka muid vanu keeli. Neil keelekursustel on nad juba kokku puutunud võõrkeelse grammatikaterminoloogiaga ning selliste eelteadmiste olemasolust lähtub ka õpik „Lingua Latina in theologia”. Seega tulevaste teoloogide ladina keele kursuse tarbeks terminite iga hinna eest maakeelde tõlkimine ei ole eriti otstarbekas tegevus. Igas õppeaines on oluline näha seoseid varemõpituga, teoloogilises ladina keeles eelkõige kreeka keelega, milles kristlik terminoloogia algselt loodi.

Vaatamata spetsiifilisele sihtrühmale on õpik siiski mõeldud algajaile. Materjali on sinna valitud vastavalt sel-

${ }^{1}$ A. Lill, Ladina keele õppimisest teoloogias. - Keel ja Kirjandus 2016, nr 2, lk 141-145. lele, kui palju on kahe semestri jooksul võimalik läbi töötada. Sellise kursuse lõpuks peaksid Tartu Ülikooli usuteaduskonna üliõpilased olema võimelised lugema tekste, mis eeldavad teadmisi klassikalisest ladina keelest, nt Vulgata ja Augustinuse „Pihtimused”.

Õpiku koostamisel ei tulnud seista valiku ees, „milles järgida traditsiooni ja milles lähtuda praegustest vajadustest", sest teoloogidele mõeldud ladina keele õpikuid on äärmiselt vähe ning traditsioonist siin rääkida ei saa. Samuti ei koondunud ,keskne küsimus ja üldse mõte, miks meil sellist õpikut vaja on, ladina keele arengute väljatoomisele kristlikus kontekstis". Keskne probleem, mis ajendas seda raamatut koostama, oli oppiku puudumine TÜ usuteaduskonna tudengite ladina keele algkursusel. „Ladina keele arengute väljatoomine kristlikus kontekstis" on eelkõige jätkukursuse teema neile, kel on sellest keelest juba ettekujutus olemas. Õpikus on üritatud leida optimaalne tasakaal klassikalise ladina keele ja olulisemate hilisemate eripärade vahel.

"Lingua Latina in theologia” keskmes ei ole „adressaatkeele jaoks eripärased raskused", vaid pigem teoloogilist konteksti tundvate oppijate viimine lähtekeele ja selle mõistmise juurde. Eestikeelset piiblitõlget võivad teoloogiatudengid tihtilugu peastki teada, seda huvitavam on uurida, millisel kujul esineb juba tuttav lause heebrea, kreeka ja ladina keeles.

Nagu retsensent väga õigesti märgib, tuleb keeleõpikus suuremat tähelepanu pöörata sagedamini esinevatele vormidele. Seda on raamatus ka tehtud, seepärast ongi vähe näiteid gerundiumi 
(teonime) ning konstruktsiooni akusatiiv infinitiiviga kasutamise kohta. Vulgatas ja hilisemates tekstides esineb neid kaunis harva. Retsensendi toodud ülevaade vormide kasutamise sagedusest on toodud klassikalise ladina keele kohta ning hilisemas ladina keeles ei pruugi see enam kehtida. Asjaolu, et õpikus on nii perfekti kui ka futuurumi partitsiibile pühendatud pool lehekülge, ei tohiks küll kummagi mõistmist takistada. Oluline on välja tuua, et need kesksõnad moodustatakse samast tüvest. Kuna partitsiipide peatükile järgneb õpikus passiivi peatükk, kajastatakse perfekti partitsiipi kui passiivi aegade moodustamisel vajalikku koostisosa rohkem ja pikemalt.

Kuna õpik ei ole mõeldud filoloogidele, siis ei kajasta see ka neid huvitavaid teemasid, nagu ladina keele ajalooline areng ja värsiõpetus. Samal põhjusel ei anna raamat põhjalikku ülevaadet ladina süntaksist ega seostest eesti keelega. Selliseid teemasid käsitleb süvitsi Anne Lille, Maria Kanteri ja Merike Ristikivi koostatud suurepärane ladina keele õpik „Studia Latina”. ${ }^{2}$ Ent kahte ühesugust ladina keele õpikut ei ole mõtet Eesti oludes välja anda. Seega vastupidi „Studia Latina” ulatuslikele seletustele on „Lingua Latina in theologia” koostatud pigem lakoonilise ja skemaatilisena. Kogemus on näidanud, et ka iseseisvalt on selle õpiku materjaliga hakkama saadud, kuigi kõigile ei pruugi see jõukohane olla.

Kuna arvustaja on tähelepanu juhtinud depoonensverbidele ja nende mõistmisele, mida tulnuks käsitleda pikemalt, siis osutaksin sellele, et õpikus „Studia Latina" on depoonenseid käsitletud veel lühemalt (lk 181-183) kui raamatus "Lingua Latina in theologia” (lk 135139) ning probleemi sellest tekkinud ei ole. Tulevased Eesti teoloogid peaksid nii passiivi kui ka depoonensite teemaga olema tuttavad juba Jaan Undi põhjalike seletustega õpikust „Uue Testamendi

${ }^{2}$ A. Lill, M. Kanter, M. Ristikivi, Studia Latina. Toim Ivo Volt. Tallinn: Eesti Keele Sihtasutus, 2002, 2004, 2015. kreeka keel algajaile". ${ }^{3}$ Kuna depoonensverbid on kasutusel ka mitmes tänapäeva keeles (nt rootsi ja uuskreeka keeles), ei tohiks nende mõistmine ja tarvitamine ka ülearu keeruline olla.

Ma ei pea otstarbekaks vale rõhuga hääldatud ladina keele sõnadele osutamist, sest see võib vale rõhu kinnistada. Üliõpilane hääldab üldjuhul ikka nii, nagu õppejõud on õpetanud. Pisut kummastust tekitas asjaolu, et pärast pikka ülevaadet ladina keele ajaloos toimunud muutustest, kõnekeele ja kirjakeele vahekorrast ja vastastikusest mõjust peab retsensent vajalikuks lisada teoloogide õpikusse eesti keelest ladina keelde tõlkimise materjali. Millisesse ladina keelde tuleks seda siis tõlkida, kas klassikalisse või keskaegsesse keelde, kirja- või kõnekeelde? Ka ei näe ma midagi halba selles, et iga õppetükk lõpeb kokkuvõttega sellest, millele tuleks vastava teema omandamisel suuremat tähelepanu pöörata.

Lõpetuseks lisan, et kõnealust õpikut välja andma õhutasid mind kolleegid ja üliõpilased TÜ usuteaduskonnast, kes olid minu publitseerimata materjalidega tutvunud ja neid kasutanud. Kuna sellesama materjali alusel on tulevased teoloogid juba aastaid ladina keelt õppinud ning kursuse edukalt läbinud, siis loodan, et õpiku olemasolu mitte ei raskenda, vaid lihtsustab selle keele õppimist.

Anne Lille täiendusettepanekud õpikule „Lingua Latina in theologia” on igati õigustatud ja teretulnud, kuid niivõrd suurt hulka materjali ei ole kahjuks võimalik paigutada väikesemahulise kursuse raamidesse. Olen omalt poolt teoloogilise suunitlusega ladina keele õppijatele abikäe juba ulatanud. Kui retsensent soovib, võib temagi seda teha. Raamatust praegu puuduva materjali saab välja anda õpiku lisana, et huviliste käsutuses oleks aines ladina keele kursuse täienduseks ning selle keele õpingute jätkamiseks.

KAARINA REIN

${ }^{3}$ J. Unt, Uue Testamendi kreeka keel algajaile. Tallinn: Logos, 1998. 